\title{
AN INTRODUCTION: THE EFFECTIVENESS OF INTERNATIONAL LAW
}

\author{
By Oona Hathaway, ${ }^{*}$ Larry Johnson, ${ }^{\dagger}$ and Fionnuala Ní Aoláin ${ }^{\ddagger}$
}

International law today touches on nearly every aspect of our lives, from the price of practically everything we purchase, to the health of the environment that surrounds us, to our ability to communicate seamlessly worldwide. These encounters serve as daily reminders that, as Louis Henkin famously put it, "almost all nations observe almost all principles of international law and almost all of their obligations almost all of the time."

Yet at the same time, there are regular reminders that not all nations, groups, or individuals observe all principles of international law or all of their obligations all of the time. International law violations such as human rights abuses, trade law breaches, and law of armed conflict violations remain all too common.

When, how, and why is international law most effective? Are there greater challenges to effectiveness in some areas of international law practice than in others? If so, what are they, and how can they be addressed? What role do domestic and international courts play in enforcing international law and thus enhancing its effectiveness? Does the increasingly intertwined transnational economy offer tools that may be used to enforce international law against states and individuals, or does it instead make international law more vulnerable by making evasion of national authority simpler? Do the challenges facing international law vary in different parts of the world, and, if so, how might those challenges be met? What role do non-state actors-nongovernmental organizations and corporations chief among them-play in making international law more or less effective? And what role should they play?

Members of the ASIL and the ILA explored these questions at the 2014 ASIL Annual Meeting, the first joint meeting in the history of these two great international law associations. This volume of the ASIL Proceedings memorializes this historic event.

\footnotetext{
* Gerard C. and Bernice Latrobe Smith Professor of International Law, Yale Law School.

Adjunct Professor of Law, Columbia Law School.

Dorsey \& Whitney Chair in Law, University of Minnesota Law School; Professor of Law, Transitional Justice Institute, University of Ulster, Belfast, Northern Ireland.
} 